\title{
Distribution and comparison of major selected elements in root of wild plant, root derived calli and various anatomical parts of cultivated Saussurea lappa: An endangered medicinal plant
}

\author{
Zaib-Un-Nisa ${ }^{1 *}$, Safdar Hussain Shah ${ }^{2}$, Ghulam Farooq ${ }^{3}$, Muhammad \\ Anwar Sajad ${ }^{4}$ and Muhammad Anwar Saleem Khan ${ }^{5}$ \\ 1. Department of Botany, Women University, Swabi, Guloo-Dheri Swabi-Topi Rd, 234302-Pakistan \\ 2. Institute of Biotechnology and Genetic Engineering (IBGE), Khyber Pakhtunkhwa Agriculture University, \\ Peshawar-Pakistan \\ 3. Department of Genetics, Hazara University, Mansehra-Pakistan \\ 4. Department of Botany, Islamia College Peshawar, Peshawar-Pakistan \\ 5. Department of Zoology, University of Swabi, Khyber Pakhtunkhwa-Pakistan \\ *Corresponding author's email:zaib2864@gmail.com
}

\section{Citation}

Zaib-Un-Nisa, Safdar Hussain Shah, Ghulam Farooq, Muhammad Anwar Sajad, Muhammad Anwar Saleem Khan. Distribution and comparison of major selected elements in root of wild plant, root derived calli and various anatomical parts of cultivated Saussurea lappa: An endangered medicinal plant. Pure and Applied Biology. Vol. 8, Issue 2, pp1478-1486. http://dx.doi.org/10.19045/bspab.2019.80087

\begin{tabular}{llll}
\hline \hline Received: 28/02/2019 & Revised: 03/05/2019 & Accepted: 10/05/2019 & Online First: 13/05/2019
\end{tabular}

\section{Abstract}

Levels of sodium $\left(\mathrm{Na}^{+}\right)$, potassium $\left(\mathrm{K}^{+}\right)$, calcium $\left(\mathrm{Ca}^{+2}\right)$ and magnesium $\left(\mathrm{Mg}^{+2}\right)$ ions were determined in the root, leaf and petiole of cultivated Sassurea lappa plant collected from Pakistan Forest Institute, Peshawar. The same ions were also analyzed in root (b) of the same plant collected from Koza Gali, Abbottabad as well as in wild plant root (c) of Kashmir hills. Potassium $\left(\mathrm{K}^{+}\right)$and sodium $\left(\mathrm{Na}^{+}\right)$in the medicinal plant, S. lappa were determined by using flame photometer (Jenway PFP 7) while $\mathrm{Ca}^{+2}$ and $\mathrm{Mg}^{+2}$ contents were measured by atomic absorption spectrophotometer (Hitachi Z-800). Significant differences were observed among all the tested samples. However, the highest level of $\mathrm{K}^{+}$was 1886.45 $\mu \mathrm{Mg}^{-1}$ found in cultivated plant petiole and its lowest concentration was $385.351 \mu \mathrm{Mg}^{-1}$ observed in shoot derived callus (callus a). Sodium content $\left(\mathrm{Na}^{+}\right)$was found higher in shoot callus (callus a) while magnesium $\left(\mathrm{Mg}^{+2}\right)$ concentration was observed high $\left(109.349 \mu \mathrm{Mg}^{-1}\right)$ in root (b) collected from Koza Gali, Abbottabad and their lower concentrations were $102 \mu \mathrm{Mg}^{-1}$ and $47.432 \mu \mathrm{Mg}^{-1}$ found in petiole and wild plant root (root c) respectively. The lowest concentration was found in case of $\mathrm{Ca}^{+2}$ in comparison of other elements. The levels of all the selected elements were highly varied in the anatomical parts of the same cultivated plant, shoot and root derived calli and between the varied regions plant roots except $\mathrm{Ca}^{+2}$. The overall levels of the elements were found in the order: $\mathrm{K}^{+}>\mathrm{Na}^{+}$ $>\mathrm{Mg}^{+2}>\mathrm{Ca}^{+2}$.

Keywords: Saussurea lappa; In vitro culture; Calli; Major elements 


\section{Introduction}

Certain elements are well thought-out as particularly desirable for successful growth of plants. If they are improperly balanced, normal growth and development does not occur. Out of eleven essential elements such as nitrogen, potassium, phosphorus, calcium, sulphur, magnesium, iron, boron, zinc, copper and manganese are absorbed from the soil by plants through their roots, six are used in comparatively larger quantities and thus are receiving major attention [1]. They are sometimes designated as the main elements for convenience. Plant growth may be retarded because these elements are actually lacking in the soil or because they become available too slowly or may be not adequately balanced by supplementary nutrients [1]. Sometimes all three of these limitations are functioning predominantly with respect to nitrogen [1]. The list of elements essential to animals is slightly different and includes sodium, although it is not necessary to the plant obviously it is desirable that grasses and other plants eaten by grazing animals should contain adequate quantities of it [2].

Potassium, sodium, magnesium and Calcium are the four major components in all the cells and extracellular fluids of organism [2]. Calcium is an alkaline-earth metal and it is essential for animals and humans, particularly in cell physiology. A deficit in Calcium can affect the formation of bone and tooth, but the excess retention can cause kidney stones. Calcium is not only a soil component, but it is an important macro element too. Calcium performs many functions in plants. It sustains the stability of the cell wall. Calcium perform different functions such as calcium signaling, response to phytohormones [2]; response to pathogen diseases elicitors [3] and response to abiotic environmental factors [4]. The ratio of calcium to phosphorus content $(\mathrm{Ca} / \mathrm{P})$ in soil, plants, fodder and human diet is an indicator of equilibrium necessary to the regular run of processes in the food chain [5]. Sodium has very vital roles in many physiological processes. It is present in extracellular fluids in humans and animals. It is accountable for depolarization of cellular membranes and water equilibrium in intra- and extracellular medium. In blood Sodium content is about 10 times more than in intracellular medium. Potassium is also an important macroelement for human. It is important because of its involvement in contraction of muscles, in lipid metabolism, in protein synthesis, electrolyte balance and maintaining the fluid in the body and is accountable in the nerve impulses sending. The necessary daily intake is between 2-4 g/day [6]. Magnesium is very important to all the cells of human beings. It is present in many enzymes involved in the metabolism of carbohydrates, lipids and proteins. In plants magnesium is an important component present in chlorophylls. Medicinal plants or parts of them are used successfully in the treatment of different kind of diseases for those therapeutically properties. The aim of this research work is to report trace elements $\left(\mathrm{Ca}^{+2}, \mathrm{Mg}^{+2}, \mathrm{Na}^{+}\right.$and $\mathrm{K}^{+}$) concentration in calluses, wild root and cultivated plant leaves, petiole and roots (different regions) of the highly medicinal plant S. lappa. Further, to know whether the concentration of the selected elements are same or show variation in the same plant parts collected from Pakistan Forest Institute (Peshawar), Abbottabad (Koza Gali) and in wild plant of Kashmir hills.

\section{Materials and methods}

The basal Murashige and Skoog (MS) media [7] was used for callus induction.

\section{Growth regulators}

2, 4-Dichlorophenoxy acetic acid (2, 4-D) and Kinetin of $1.0 \mathrm{mg} / \mathrm{l}$ and $0.25 \mathrm{mg} / \mathrm{l}$ were used for callus initiation. The $\mathrm{pH}$ of $\mathrm{MS}$ media for best callus induction, direct and indirect organogenesis was optimized as 5.8. For semisolid medium preparation, the nutrient solution was transferred to a $200 \mathrm{ml}$ 
of conical flask and added $9 \mathrm{~g}$ of agar. The agar was dissolved completely and uniformly, the flask contained medium was heated in a microwave. Dispensed medium containing agar into open mouth flasks/test tubes and covered with double folds of aluminum foil [8].

\section{Sterilization of the media}

The media were dispensed in flasks and then sterilized for 20 minutes by autoclaving at $121{ }^{\circ} \mathrm{C}$. Other equipments like scalpel, spatulas and forceps were also sterilized with media. After autoclaving, the whole materials were directly transferred to the laminar flow cabinet, where subjected for 20 minutes to ultra violet (UV) radiation. The whole culture was carried out in a sterilized and aseptic environment in laminar flow cabinet [9].

\section{Relative growth rate}

Callus was harvested after several subsequent subcultures. For the determination of the callus relative growth rate (RGR), the method followed by Nisa et al. (9) was used. Callus initial fresh weight and final fresh weight was recorded. The callus growth was expressed as relative growth rate week $^{-1}$ using equation (A) as given below:

RGR $=$ In (Final weight of callus) - In (Initial weight) / 2 week $^{-1}$

\section{Plant materials}

The wild growing plant was collected from Kashmir hills (root c) whereas cultivated plant (root a, leaves and petiole) was collected in the same season (18-08-2014) from Pakistan Forest Institute Peshawar and root (b) from Koza Gali, Abbottabad. The selected plant is critically endangered and medicinally important.

\section{Inoculation}

From micropropagated plant, shoot and root explants were excised with the help of sterilized cutter and inoculated by using forceps in $100 \mathrm{ml}$ flasks containing MS medium fortified with $2-4 \mathrm{D}+\mathrm{Kn}(1 \mathrm{mgL}$ $\left.1+0.25 \mathrm{mgL}^{-1}\right)$. Single explant was inoculated per flask. In order to get maximum sterilization, forceps were kept in ethanol and then burned with a flame after every inoculation. The whole process of inoculation was carried out in a closed proximity to the flame to diminish the chance of contamination. The cultured flasks were sealed tightly with aluminum foil and para film and labeled after inoculation. Then placed in growth room, where the cultured flasks were kept under dark conditions [8]. Calluses were collected after 25 subculture and 15 days was single subculture duration.

The cultivated plant leaf petiole, lamina and root (root a) collected from botanical garden of Pakistan Forest Institute, Peshawar, root (b) and root (c) from Koza gale, Abbottabad and Kashmir hills (wild) respectively. The Collected plant materials and sho calli (callus a, callus b)were dried in shade; extracted and ionic content $\left(\mathrm{K}^{+}, \mathrm{Na}^{+}, \mathrm{Ca}^{++}\right.$ and $\mathrm{Mg}^{++}$) was determined by the method of chase [10].

For digestion process, weighed shade dried samples were placed in kjeldahl flask. $10 \mathrm{ml}$ of concentrated nitric acid $\left(\mathrm{HNO}_{3}\right)$ was added in each flask and heated on the sand bath in a fume hood, until the digested materials reached to $1 \mathrm{ml}$.

Afterward the extract was cold and finally the volume was made up to $10 \mathrm{ml}$ using distilled water. Diluted the concentrated $\mathrm{HNO}_{3}$ to $10 \%$ and the standard solutions of cations was prepared in it [10]. The $\mathrm{K}^{+}$and $\mathrm{Na}^{+}$contents were measured by flame photometer (Jenway PFP 7) while $\mathrm{Ca}^{+2}$ and $\mathrm{Mg}^{+2}$ contents were measured by atomic absorption spectrophotometer (Hitachi Z800). The entire laboratory work was carried out in Plant Tissue Culture Laboratory, Institute of Biotechnology and Genetic Engineering and Soil Science Department of Agriculture University, Peshawar. 


\section{Results and discussion}

The calli data of RGR week ${ }^{-1}$ is illustrated in the (Figure 1). The RGR week ${ }^{-1}$ of shoot and root calli with their relative dry weight week $^{-1}$ was calculated on the basis of calluses fresh and dry weight. Maximum (0.182 and 0.0656 RGR week ${ }^{-1}$ ) RGR of fresh and dry callus was observed in root derived callus compared to shoot derived callus (0.1591 fresh RGR week ${ }^{-1}$ and 0.026 dry RGR week $\left.{ }^{-1}\right)$. It is clear that root and petiole explants of micropropagated plant are efficient in callus initiation while lamina took more days [8] and also produce less amount of calli. Explant types (shoot and root) were different in their ability to produce callus. Similar findings were reported by Abdel-Rahim et al., [11], Prasanna et al., [12] and Huang et al., [13]. Significant differences were observed in these explants when the results were analyzed using one way ANOVA at $\alpha<0.05$. In contrast, Zhang et al., [14] obtained nonsignificant differences in the response the three explants (shoot and roots) of Brassica napus. Such different results might be attributed to the different species and hence, the different genetic potential of regeneration.

No growth was observed on growth regulators free medium. The ANOVA showed overall no significant difference between the two types callus (Figure 1).

\section{Monovalent cations analysis} Sodium ion $\left(\mathrm{Na}^{+}\right)$

Data indicating sodium ions concentration is shown in (Figure 2). In callus (a), the content of $\mathrm{Na}$ ions $\left(408.583 \mu \mathrm{Mg}^{-1}\right)$ was significantly higher than all other samples. It might be due to high absorption of sodium from the MS media.

Root b $\left(280.508 \mu \mathrm{Mg}^{-1}\right)$ and callus b (273.911 $\left.\mu \mathrm{Mg}^{-1}\right)$ showed no significant difference from each other, but significantly different from other samples that might be due to the accumulation of $\mathrm{Na}^{+}$ throughout the whole period in growth of root [15]. Root a $\left(209.81 \mu \mathrm{Mg}^{-1}\right)$ also give similar results approximately but has higher concentration than root $\mathrm{c}\left(178.737 \mu \mathrm{Mg}^{-1}\right)$, lamina $\left(166.808 \mu \mathrm{Mg}^{-1}\right)$ and petiole $(102$ $\left.\mu \mathrm{Mg}^{-1}\right)$. Minimum concentration than all other samples was indicated by petiole. It was observed that accumulation of $\mathrm{Na}^{+}$ion is less in leaf compared to root. As reported by Shirazi et al. [17] the leaves often have a lower concentration of $\mathrm{Na}^{+}$compared to roots. The ANOVA showed higher significant difference in sodium content of test samples (Figure 2).

\section{Potassium ion $\left(\mathbf{K}^{+}\right)$}

Data regarding Potassium ions concentration is shown in (Figure 3). The figure indicates significant difference between test samples. The content of $\mathrm{K}^{+}$ ions was significantly higher $\left(1886.45 \mu \mathrm{Mg}^{-}\right.$ $\left.{ }^{1}\right)$ in plant petiole than all other test samples. The present work agreed with the work of Besford and Maw [17]. They reported that plant petioles contain high concentration of potassium. In callus (a) $\mathrm{K}^{+}$content was higher (985.458) compared to other samples. Lamina $\left(784.577 \mu \mathrm{Mg}^{-1}\right)$ was third that showed high concentration which indicate the accumulation of $\mathrm{K}^{+}$in shoot due to its enlarged cell vacuole. Under typical physiological conditions, plants maintain a high $\mathrm{K}^{+} / \mathrm{Na}^{+}$ratio in their cytosol with relatively high $\mathrm{K}^{+}(100-200 \mathrm{mM})$ and low $\mathrm{Na}^{+}$concentrations $(1-10 \mathrm{mM})$ [18]. The concentration was gradually decreased in root a $\left(645.198 \mu \mathrm{Mg}^{-1}\right)$, callus b (493.306 $\left.\mu \mathrm{Mg}^{-1}\right)$, root $\mathrm{c}\left(459.806 \mu \mathrm{Mg}^{-1}\right)$ and root $\mathrm{b}$ $\left(385.351 \mu \mathrm{Mg}^{-1}\right)$. Less content was found in root (b). Among roots of different regions, The high concentration of $\mathrm{K}^{+}$in root (a) might be due to root absorption capacity, geometry in absorbing root surface, plant demand and water flux rate [19] from the soil solution. In respective data of $\mathrm{K}^{+}$, maximum accumulation was found in leaves compared to roots. ANOVA showed 
higher significant difference in the potassium content of all parameters.

\section{Divalent cation analysis}

\section{Calcium ion $\left(\mathrm{Ca}^{++}\right)$}

Data regarding calcium ions concentration is shown in (Figure 4). The figure indicates most similar concentration of $\mathrm{Ca}^{++}$found in all types of material that was petiole (19.866 $\left.\mu \mathrm{Mg}^{-1}\right)$, lamina $\left(19.761 \mu \mathrm{Mg}^{-1}\right)$, callus a $\left(19.177 \mu \mathrm{Mg}^{-1}\right)$, root a $\left(19.097 \mu \mathrm{Mg}^{-1}\right)$, root $\mathrm{c}\left(18.9263 \mu \mathrm{Mg}^{-1}\right)$, root b $\left(18.07 \mu \mathrm{Mg}^{-1}\right)$ and callus b (18.066 $\left.\mu \mathrm{Mg}^{-1}\right)$. The ANOVA showed non-significant difference in calcium content of test samples. $\mathrm{Ca}^{++}$ content has consistently the least value in all plant and calli samples. Petioles contained slightly high concentration of calcium compare to other plants parts. According to Karley and White [20] Calcium (Ca) concentration was found as increasing in the order stem < leaf < petioles among the cultivated plants. Further reported that most plant $\mathrm{Ca}^{++}$is stored in leaves, but the present result differed with them. Statistically, $\mathrm{Ca}^{++}$concentration not differed significantly only within plant parts, but also among the different region plant roots (Figure 4).

\section{Magnesium ion $\left(\mathrm{Mg}^{++}\right)$}

Data regarding magnesium ions concentration is shown in (Figure 5). This figure indicates significant difference between tested samples. There was nonsignificant difference between root $b$ (109.349 $\left.\mu \mathrm{Mg}^{-1}\right)$, lamina $\left(107.541 \mu \mathrm{Mg}^{-1}\right)$, and root a $\left(104.978 \mu \mathrm{Mg}^{-1}\right)$ in $\mathrm{Mg}^{++}$, but showed higher concentration than callus $\mathrm{b}$ $\left(72.327 \mu \mathrm{Mg}^{-1}\right)$, callus a $\left(63.823 \mu \mathrm{Mg}^{-1}\right)$ and root b (47.432 $\left.\mu \mathrm{Mg}^{-1}\right)$. Callus (b) and callus (a) showed non-significant results from each other, but higher in concentration than root (c) which showed minimum $\mathrm{Mg}^{++}$ concentration than all samples. These differences in concentrations might be attributed due to the requirement of the plant or availability in the soil. Our findings are in agreement with Baligar and Barber [17]. The ANOVA showed a non-significant difference in ionic content of magnesium in tested samples. However, the level of $\mathrm{Mg}^{++}$ was high in root derived callus and the accumulation of $\mathrm{Mg}^{++}$was also observed high in root followed by lamina and petiole which match with the results of Adeyeye [3].

Overall results showed a wide range of variation in the four $\mathrm{Na}^{+}, \mathrm{K}^{+}, \mathrm{Ca}^{++}$and $\mathrm{Mg}^{++}$) elemental constituents of different plants parts. The presence and concentration of these elements from different regions, roots of the same plant ( $S$. lappa) were dependent on the composition of the soil, water and fertilizers used as well as permissibility, selectivity and absorption capacity of plants for the uptake of these elements. Hence, the observed variations in concentration of the elements are attributed to the nature of the plant as well as its surroundings [21]. 
Nisa et al.

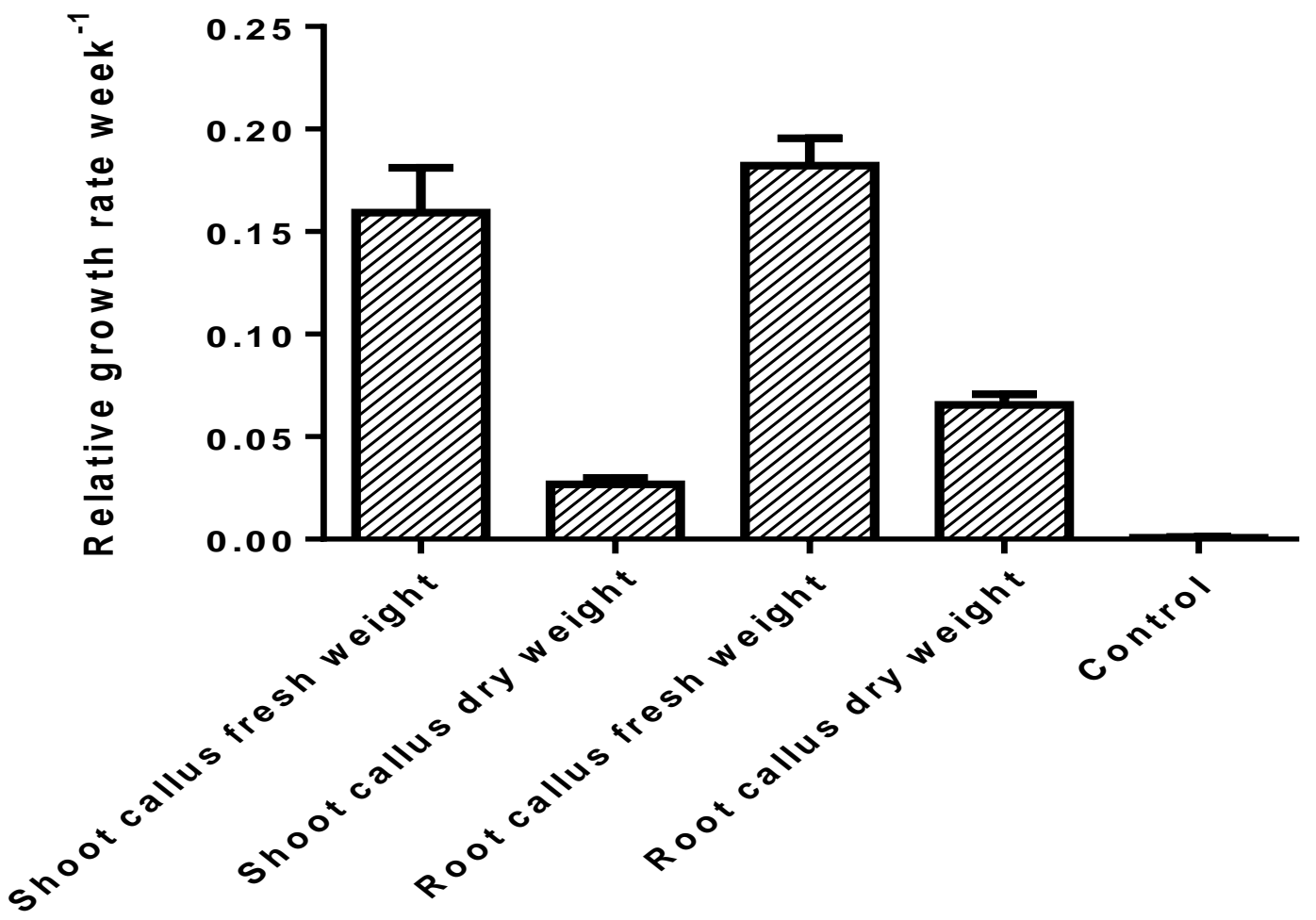

Figure 1. Relative growth rate of shoot callus fresh weight, shoot callus dry weight, root callus fresh weight and root callus dry weight

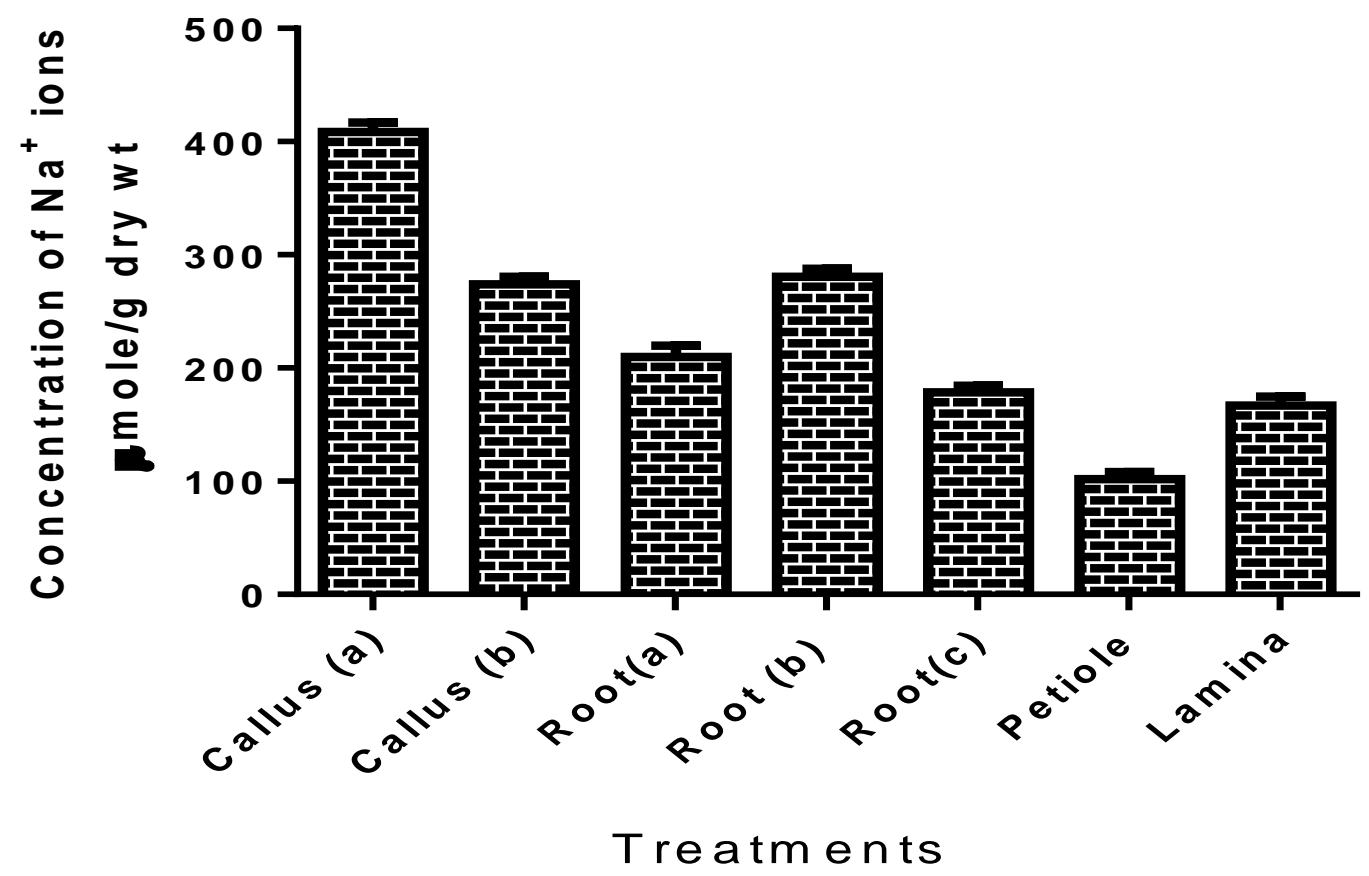

Figure 2. Concentration of $\mathrm{Na}^{+}$in test samples. Differences between graphs are the means of three replicates $\pm \mathrm{SD}$ 


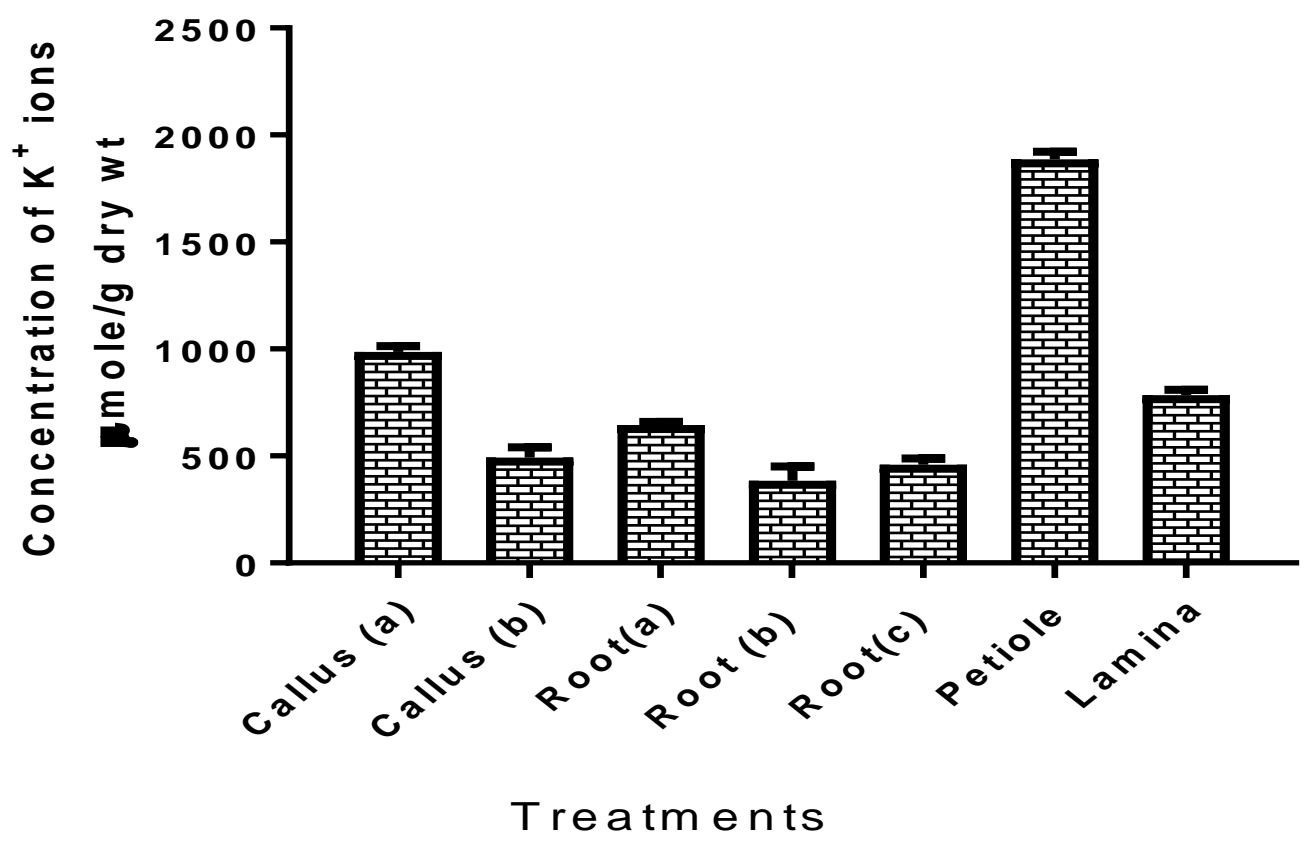

Figure 3. Concentration of $\mathrm{K}^{+}$in test samples. Differences between graphs are the means of three replicates $\pm \mathrm{SD}$

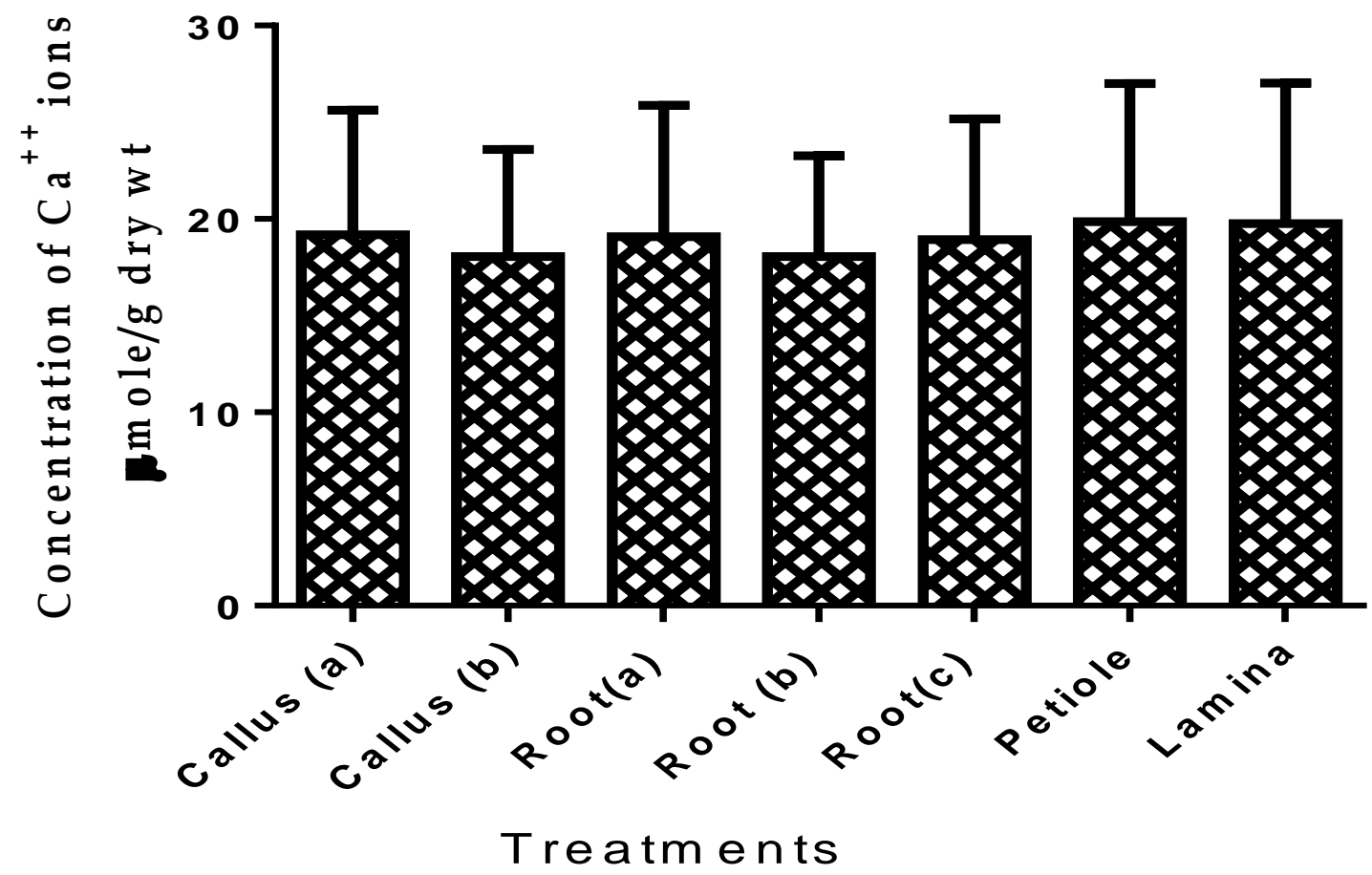

Figure 4. Concentration of $\mathrm{Ca}^{++}$in test samples. Differences between graphs are the means of three replicates $\pm \mathrm{SD}$ 
Nisa et al.

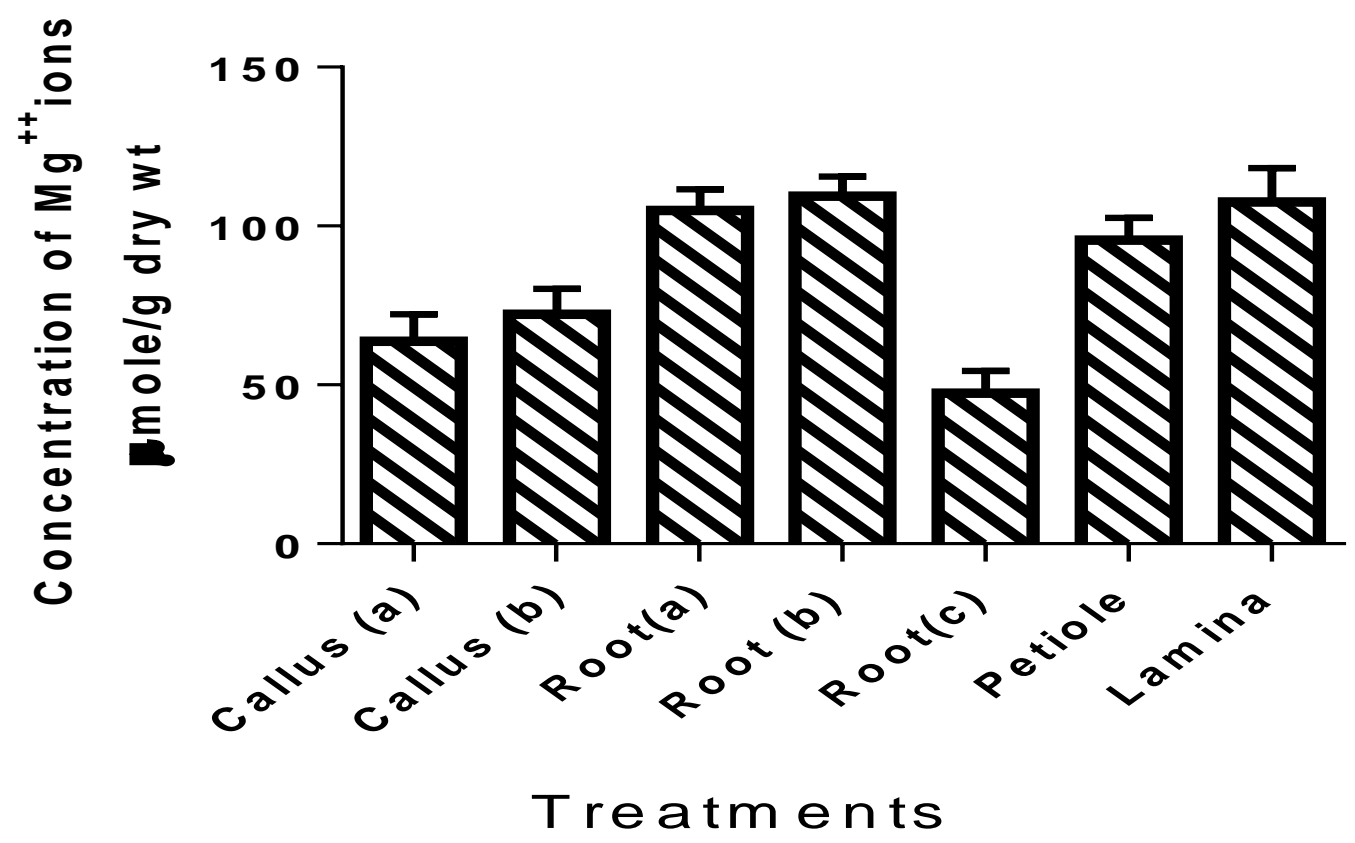

Figure 5. Concentration of $\mathrm{Mg}^{++}$in tested samples. Differences between graphs are the means of three replicates \pm SD

\section{Conclusion}

It is concluded from our current research work that the distributions of $\mathrm{K}^{+}, \mathrm{Na}^{+}, \mathrm{Mg}^{+2}$ and $\mathrm{Ca}^{+2}$ were highly varied in the anatomical parts of the same plant. Variation was found in the level of the concentration of these elements in the parts of the same plants collected from different regions. Overall the level of $\mathrm{K}^{+}$was found high in the selected plant followed by $\mathrm{Na}^{+}, \mathrm{Mg}^{+2}$ and then $\mathrm{Ca}^{+2}$.

\section{Authors' contributions}

Conceived and designed the experiments:

ZU Nisa \& SH Shah Performed the experiments: ZU Nisa, Analyzed the data: ZU Nisa, G Farooq \& MA Sajad, Contributed materials/analysis tools: $G$ Farooq \& SH Shah, Wrote the paper: ZU Nisa, MA Sajad \& MAS Khan.

\section{References}

1. Lyon TL, Buckman HO \& Brady NC (1952). The Nature and Properties of Soils, 5th ed., the Macmillan Company: New York; pp. 20-44.
2. Ahn PM (1970). West African Soils, Oxford University Press: Oxford; pp. 20-100.

3. Adeyeye EI (2005). Distribution of major elements ( $\mathrm{Na}, \mathrm{K}, \mathrm{Ca}, \mathrm{Mg}$ ) in the various anatomical parts of fadama crops in ekiti state, Nigeria. Bull Chem Soc Ethiop 19(2): 175-183.

4. Walsh LM (1971). Instrumental Methods for Analysis of Soils and Plant Tissue, Soil Society of America: Madison, Wisconsin, U.S.A.; pp. 2732.

5. Varian Techtron (1975). Basic Atomic Absorption Spectroscopy - A Modern Introduction, Varian Techtron: Springvale, Australia; pp. 104-106.

6. Steel RGD \& Torrie JH (1960). Principles of Procedures of Statistics, McGraw-Hill: London; pp. 1- 360.

7. Murashige $T$ \& Skoog F (1962). A revised medium for rapid growth and bioassays with tobacco tissue culture. Physiol Plant 15(1): 473-479. 
8. Nisa ZU, Jan S \& Shah SH (2016). Standardization of protocol for the surface sterilization and callus induction of Saussurea lappa: an endangered medicinal plant. Int $J$ Biosci 9(1): 324330.

9. Nisa ZU, Jan S, Sajad MA, Shah SH, Faroq G \& Ali H (2018). Micropropagation through apical shoot explants and morphogenic potential of different explants of Saussurea lappa: An endangered medicinal plant. Pure Appl Biol.

10. Chase DS (1978). Botanical and economic aspects of vegetative part of lowe Swansea.

11. Abdel-Rahim EAO, Abdel-Fatah M, Shemy HAI \& Abd Samei MB (1998). Growth of date palm callus as affected by growth regulators, sugars as carbon source and amino acids as organic nitrogen source. Arab J. Biotechnol 1 (1): 99-106.

12. Parmessur Y, Aljanabi S, Saumtally S \& Dookun-Saumtally A (2002). Sugarcane yellow leaf virus and sugarcane yellows phytoplasma: elimination by tissue culture. Plant Pathol 51(5): 561-566.

13. Huang B, Han L, Li S \& Yan (2015). Optimization of induction, subculture conditions, and growth kinetics of Angelica sinensis (Oliv.) Diels callus. Pharmacogn Mag 11(43): 574578.

14. Zhang JL, Mi SE \& Luan WJ (1995). Analysis of callus induction conditions of Angelica sinensis (Oliv.) Diels. Gansu. Agric Sci Technol 11: 8-10.

15. Iwahashi $M$, Tachibana $Y$ \& Ohta $Y$ (1982). Accumulation of calcium, magnesium, potassium and sodium with growth of individual leaves, petioles and stems of cucumber plants. Soil Sci. Plant Nutr 28: 441-449.

16. Shirazi MU, Rajput MT, Khan MA, Ali M, Mujtaba SM, Shereen A, Mumtaz S $\&$ Ali M (2011). Growth and ions $\left(\mathrm{Na}^{+}\right.$, $\mathrm{K}^{+}$and $\mathrm{Cl}^{-}$) accumulating pattern of some Brassica genotypes under saline sodic field condition. Pak. J Bot 43(6): 2661-2664.

17. Besford RT and G. A. Maw. 1974. Uptake and distribution of potassium in tomato plants. Plant Soil 41(3): 601618.

18. Higinbotham N (1973). Electropotentials of plant cells. Annu. Rev. Plant Physiol Plant Mol Biol 24 (1973), pp 25-46.

19. Baligar VC \& Barber SA (1978). Use of $\mathrm{K} / \mathrm{Rb}$ ratio to characterize potassium uptake by plant roots growing in soil. Soil Sci Soc Am J 42: 575-579.

20. Karley AJ \& White PJ (2009). Moving cationic minerals to edible tissues: Potassium, magnesium, calcium. Curr Opin Plant Biol 12: 291-298.

21. Rajurkar NS \& Damame MM (1997). Elemental analysis of some herbal plants used in the treatment of cardiovascular diseases by NAA and AAS. J Radio analytical Nuclear Chem 219 (1): 77-80. 